\title{
PENGGUNAAN STANDARD WBS (WORK BREAKDOWN STRUCTURE) PADA PROYEK BANGUNAN GEDUNG
}

\author{
(Using of Standardized WBS (Work Breakdown Structure) in Building Project) \\ Ayu Herzanita ${ }^{1}$ \\ ${ }^{1}$ Program Studi Teknik Sipil Universitas Pancasila \\ E-mail:ayu.herzanita@univpancasila.ac.id
}

\begin{abstract}
ABSTRAK
WBS (Work Breakdown Structure) memegang peranan penting dalam setiap proyek konstruksi. WBS merupakan hirarki penurunan lingkup pekerjaan hingga menjadil level terkecil yang disebut dengan paket pekerjaan, sehingga memudahkan dalam proses pengelolaan dan pengendalian proyek. Permasalahan yang terjadi saat ini, banyak kontraktor di Indonesia, baik kontraktor besar maupun kecil kurang memahami pentingnya penggunaan WBS dalam sebuah proyek konstruksi. Hal tersebut menyebabkan kinerja proyek kurang maksimal, terutama pada kinerja biaya dan waktu. Saat ini telah dikembangkan standard WBS untuk proyek bangunan gedung. Di dalam penelitian ini akan melihat kinerja biaya dan waktu proyek dari penggunaan standard WBS bangunan gedung. Sampel yang digunakan dalam penelitian ini adalah proyek-proyek yang telah menerapkan penggunaan standard proyek. Proyek-proyek tersebut antara lain proyek Gedung X, Gedung Kuliah Y, dan Gedung Fasilitas Olah Raga Z. Metode yang digunakan dalam penelitian ini adalah dengan pendekatan EVM (Earn Value Method), pengumpulan data dengan menggunakan kuisioner. Hasil penelitian menunjukkan bahwa dengan menggunakan standar WBS berpengaruh terhadap kinerja biaya dan waktu. Kinerja biaya dan waktu yang baik ditunjukkan pada proyek Gedung X dan Gedung Kuliah Y. Sedangkan kinerja biaya dan waktu pada Gedung Fasilitas Olah Raga Z cenderung tidak stabil. Hal ini dikarenakan item pekerjaan yang ada pada standar WBS kurang sesuai dengan kondisi proyek, sehingga perlu dilakukan penyesuaian item pekerjaan.
\end{abstract}

Kata Kunci: standar WBS, kinerja biaya, kinerja waktu

\begin{abstract}
WBS (Work Breakdown Structure) plays an important role in every construction project. WBS is a hierarchy of decreasing scope of work to become the smallest level called a work package, making it easier in the process of project management and control. The current problem is that many contractors in Indonesia, both large and small contractors, do not understand the importance of using WBS in a construction project. This causes project performance to be less than optimal, especially on cost and time performance. Currently, WBS standards have been developed for building projects. In this study will look at the cost and time performance of the project from the use of WBS standard building. The sample used in this study are projects that have applied the use of project standards. The projects include Building $X$, Lecture Building Y, and Sports Facility Building Z. The method used in this study is the EVM (Earn Value Method) approach, collecting data using questionnaires. The results showed that using the WBS standard had an effect on cost and time performance. Good cost and time performance is shown in the Building $X$ and Lecture $Y$ buildings. While the cost and time performance of the $Z$ Sports Facility Building tends to be unstable. This is because the work items that exist in the WBS standard are not in accordance with the project conditions, so it is necessary to adjust work items.
\end{abstract}

Keywords: standardized WBS, cost performance, time performance 


\section{PENDAHULUAN}

Proyek bangunan gedung merupakan proyek infrastruktur yang cukup banyak jumlahnya saat ini, dimulai dari pembangunan hotel, apartemen, sekolah, bangunan pemerintah maupun gedung untuk peruntukan lainnya. Dari banyaknya jumlah pembangunan gedung di Indonesia, terjadi permasalahan yang cukup kompleks, sehingga harus ada solusinya. Masalah umum yang dihadapi dalam proyek pembangunan gedung adalah buruknya kinerja biaya dan waktu.

Keberhasilan kinerja biaya dan waktu pada proyek konstruksi ditandai dengan sesuainya perencanaan anggaran biaya dan jadwal dengan pelaksanaan pekerjaan. Kenyataannya, masih banyak terjadi pembengkakan biaya dan mundurnya waktu penyelesaian pekerjaan. Menurut Van Wyngaard, dkk, 2012, keberhasilan proyek dipengaruhi kriteria kinerja, antara lain biaya, waktu dan lingkup, yang disebut dengan triple constraint.

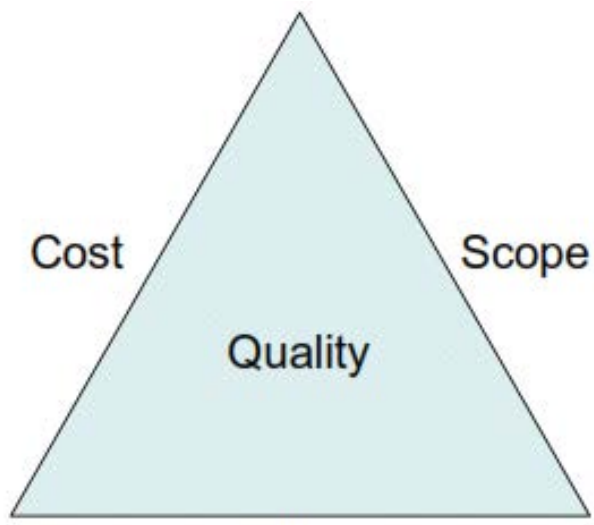

Time

Gambar 1. Triple Constraint Manajemen Proyek Sumber: Van Wyngaard, dkk, 2012

Triple constrain di dalam proyek saling berkaitan satu sama lain dan dapat bergerak secara dinamis. Sebagai contoh jika suatu proyek berjalan dengan lingkup yang tetap, maka biaya proyek akan mengkuti jadwal pekerjaan. Begitu pula dengan ketika waktu proyek yang tetap, maka lingkup produk akhir bergantung pada anggaran dan sumber daya uang tersedia (Van Wyngaard, dkk, 2012).

Begitu pentingnya kesetimbangan antara lingkup, waktu dan biaya bagi keberhasilan sebuah proyek. Oleh karen itu, melalui penelitian ini akan menilai kinerja biaya dan waktu dari proyek pembangunan gedung berdasarkan lingkup pekerjaannya.

Menurut PMBOK edisi ke-6, 2018, di dalam perencanaan lingkup proyek terdapat proses-proses yakni, mengumpulkan persyaratan, menentukan lingkup pekerjaan, serta membuat WBS (Work Breakdown Structure). WBS ini yang kemudian menjadi dasar pada kontraktor dalam menyelesaikan pekerjaannya. Di dalam perencanaan proyek, WBS sebagai dasar dalam membuat jadwal pekerjaan, menghitung biaya, menentukan sumber daya yang dibutuhkan, memperhitungkan risiko pekerjaan, termasuk dapat digunakan kegiatan pemantauan dan pengendalian proyek.

Di dalam PMBOK edisi ke-6, 2018 disebutkan WBS merupakan hirarki dari lingkup proyek yang harus diperhatikan oleh anggota tim proyek untuk mencapai tujuan proyek dan mencapai persyaratan hasil akhir (deliverable). Level terkecil dari sebuah WBS disebut dengan paket pekerjaan. Sebuah paket pekerjaan dapat digunakan pada sebuah kelompok kegiatan dimana pekerjaan dijadwalkan, diestimasi, dimonitoring dan dikontrol. Pada literatur lainnya WBS termasuk hirarki dan analisis level per level dari pelaksanaan proyek dan secara umum merupakan proyek yang diturunkan hingga mendetil (Akrami, 2015).

Permasalahan yang terjadi saat ini, banyak kontraktor di Indonesia, baik kontraktor besar maupun kecil kurang memahami pentingnya penggunaan WBS dalam sebuah proyek konstruksi. Sehingga kinerja proyek tidak sesuai dengan sasaran yang diinginkan. Kualitas produk yang dihasilkan maupun kinerja biaya dan waktu tidak tercapai.

Untuk menanggulangi permasalahan tersebut, saat ini telah dikembangkan standar WBS untuk pekerjaan konstruksi, khususnya untuk konstruksi bangunan gedung. Manfaat penggunaan standar WBS antara lain meminimalisir pelebaran lingkup proyek, memastikan produk yang dihasilkan sesuai dengan persyaratan, mengurangi pekerjaan berulang (rework), menghindari pembengkakan biaya dan waktu proyek (Hans, 2013).

Dengan telah dikembangkannya standar WBS untuk proyek konstruksi, khususnya proyek bangunan gedung, diharapkan permasalahan yang sering terjadi di dalam pelaksanaan proyek dapat diatasi. Oleh karena itu, melalui penelitian ini akan melihat dampak penggunaan standar WBS terhadap kinerja biaya dan waktu proyek. Selain itu, untuk melihat keseuaian standar WBS ini dapat dipakai untuk semua jenis gedung secara umum.

Berdasarkan penelitian yang dilakukan oleh Supriadi, dkk, 2017, standar WBS yang dikembangkan adalah untuk proyek bangunan apartemen. Dengan pembagian level lingkup pekerjaan menjadi 5 (lima) level, yang terdiri dari:

- Level 1: Nama Proyek

- Level 2: Rumpun Pekerjaan

- Level 3: Zona Pekerjaan

- Level 4: Jenis Pekerjaan

- Level 5: Paket Pekerjaan 


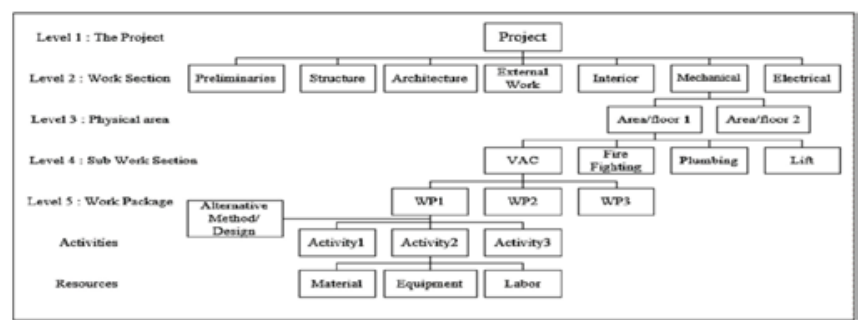

Gambar 2. Standar WBS untuk Proyek Pembangunan Apartemen

Sumber: Supriadi, dkk, 2017

\section{METODE}

Metode yang digunakan dalam penelitian ini adalah dengan pendekatan EVM (Earned Value Method). Metode ini digunakan karena yang paling mudah dalam pengukuran kinerja biaya dan waktu proyek. Di dalam pengukuran kinerja biaya dan waktu proyek, EVM menghubungkan 3 (tiga) dimensi, yakni lingkup, jadwal dan anggaran biaya (PMI, 2005).

Pengumpulan data adalah dengan melakukan kuisioner dengan memberikan pertanyaan kepada responden mengenai penggunaan standar WBS di proyeknya. Responden merupakan orang-orang yang langsung menangani proyek seperti kepala proyek atau site manager.

Indikator penilaian kinerja biaya dan waktu tersebut diterjemahkan ke dalam Cost Varians (CV) dan Schedule Varians (SV). CV merupakan nilai selisih yang diperoleh setelah paket-paket pekerjaan selesai dengan biaya aktual penyelesaian pekerjaan. Nilai positif menunjukkan paket pekerjaan yang diselesaikan lebih besar dibanding dengan biaya yang dikeluarkan. Nilai negatif menunjukkan paket pekerjaan yang diselesaikan lebih rendah dari biaya yang dikeluarkan.

Sedangkan nilai SV positif menunjukkan paket-paket pekerjaan yang diselesaikan lebih banyak dibanding jadwal rencana. Nilai SV negatif menunjukkan paketpaket pekerjaan yang diselesaikan lebih sedikit dari jadwal rencana.

Tabel 1. Analisa Varian

\begin{tabular}{ccl}
\hline SV & CV & \multicolumn{1}{c}{ Keterangan } \\
\hline Positif & Positif & $\begin{array}{l}\text { Pekerjaan terlaksana lebih cepat dari jadwal dengan biaya } \\
\text { lebih kecil dari pada anggaran }\end{array}$ \\
\hline Nol & Positif & $\begin{array}{l}\text { Pekerjaan terlaksana tepat sesuai jadwal dengan biaya lebih } \\
\text { rendah dari anggaran }\end{array}$ \\
\hline Positif & Nol & $\begin{array}{l}\text { Pekerjaan lebih cepat dari jadwal dengan biaya sesuai } \\
\text { anggaran }\end{array}$ \\
\hline Nol & Nol & Pekerjaan sesuai dengan jadwal dan anggaran biaya \\
\hline Nol & Negatif & $\begin{array}{l}\text { Pekerjaan selesai terlambat dengan biaya lebih tinggi dari } \\
\text { anggaran }\end{array}$ \\
\hline Negatif & Negatif & $\begin{array}{l}\text { Pekerjaan terlaksana sesuai dengan jadwal dengan biaya } \\
\text { lebih tinggi dari anggaran }\end{array}$ \\
\hline Positif & Negatif & $\begin{array}{l}\text { Pekerjaan selesai terlambat dengan biaya sesuai anggaran } \\
\text { Pekerjaan selesai lebih cepat dari jadwal dengan biaya di }\end{array}$ \\
\hline
\end{tabular}

Sumber: Messah, dkk, 2013
Sampel yang digunakan dalam penelitian ini adalah proyek-proyek yang telah menerapkan standar WBS dalam pelaksanaan pekerjaannya. Proyek-proyek tersebut antara lain, proyek pembangunan gedung $X$, proyek pembangunan gedung kuliah $\mathrm{Y}$, dan proyek pembangunan gedung olah raga $Z$.

Proyek-proyek tersebut akan diamati selama tiga bulan pelaksanaan mengenai kinerja biaya dan waktu menggunakan pendekatan EVM. Penilaian kinerja biaya dan waktu proyek menggunakan pendekatan EVM tersebut terdiri dari (Sediyanto \& Hidayat, 2017):

- Pekerjaan terlaksana lebih cepat dari jadwal dengan biaya lebih kecil dari pada anggaran.

- Pekerjaan terlaksana tepat sesuai jadwal dengan biaya lebih rendah dari anggaran.

- Pakerjaan terlaksana sesuai anggaran dan selesai lebih cepat dari pada jadwal.

- Pekerjaan terlaksana sesuai jadwal dan anggaran.

- Pekerjaan selesai terlambat dan biaya lebih tinggi dari anggaran.

- Pekerjaan terlaksana sesuai jadwal dengan menelan biaya di atas anggaran.

- Pekerjaan selesai terlambat dan menelan biaya sesuai anggaran.

- Pekerjaan selesai lebih cepat dari pada rencana dengan menelan biaya di atas anggaran. 
Untuk memudahkan para responden dalam menentukan kinerja, maka pengukuran kinerja biaya dan waktu dibagi menjadi 5 (lima) kategori menggunakan skala likert's. Pembagian skala kinerja biaya dan waktu dalam penelitian ini ditunjukkan pada Tabel 1 dan Tabel 2 berikut ini.

Tabel 1. Pengukuran Kinerja Biaya

\begin{tabular}{ll}
\hline \multicolumn{1}{c}{ Kinerja Biaya } & \multicolumn{1}{c}{ Skala } \\
\hline Dibawah budget, lebih dari 5\% & $\mathrm{CV}=+2$ \\
\hline Dibawah budget, kurang dari 5\% & $\mathrm{CV}=+1$ \\
\hline Sesuai budget & $\mathrm{CV}=0$ \\
\hline Melebihi budget, kurang dari $5 \%$ & $\mathrm{CV}=-1$ \\
\hline Melebihi budget, lebih dari 5\% & $\mathrm{CV}=-2$ \\
\hline
\end{tabular}

Tabel 2. Pengukuran Kinerja Waktu

\begin{tabular}{ll}
\hline \multicolumn{1}{c}{ Kinerja Waktu } & Skala \\
\hline Lebih cepat dari jadwal, lebih dari 7 hari & SV $=+2$ \\
\hline Lebih cepat dari jadwal, kurang dari 7 hari & SV $=+1$ \\
\hline Sesuai jadwal & SV $=0$ \\
\hline $\begin{array}{l}\text { Lebih lambat dari rencana, kurang dari } 7 \\
\text { hari }\end{array}$ & SV $=-1$ \\
\hline Lebih lambat dari rencana, lebih dari 7 hari & SV $=-2$ \\
\hline
\end{tabular}

Di dalam penelitian ini selain untuk melihat kinerja biaya dan waktu proyek dari penggunaan standar WBS pada bangunan gedung, juga akan melihat apakah standar WBS bangunan gedung ini dapat digunakan untuk seluruh bangunan gedung secara umum. Instrumen penelitian yang digunakan untuk permasalahan tersebut adalah dengan kuisioner, berupa pertanyaan lanjutan mengenai dampak penggunaan standar WBS pada proyek bangunan gedung.

\section{HASIL DAN PEMBAHASAN}

Berdasarkan hasil penyebaran kuisoner kepada para responden, maka diperoleh hasil kinerja biaya dan waktu dari ketiga proyek yang telah menerapkan standar WBS dalam pelaksanaan proyeknya masing-masing. Hasil kinerja biaya dari masing-masing proyek dapat dilihat pada Tabel 3. Sedangkan kinerja waktu dari masingmasing proyek dapa dilihat pada Tabel 4.

Tabel 3. Kinerja Biaya Proyek

\begin{tabular}{cccc}
\hline Bulan & Proyek 1 & Proyek 2 & Proyek 3 \\
\hline $\mathbf{1}$ & 0 & 0 & -1 \\
\hline $\mathbf{2}$ & 0 & 0 & -2 \\
\hline $\mathbf{3}$ & 0 & 0 & 1 \\
\hline
\end{tabular}

Tabel 4. Kinerja Waktu Proyek

\begin{tabular}{cccc}
\hline Bulan & Proyek 1 & Proyek 2 & Proyek 3 \\
\hline $\mathbf{1}$ & 1 & 0 & 2 \\
\hline $\mathbf{2}$ & 2 & 0 & 0 \\
\hline $\mathbf{3}$ & 2 & 0 & -1 \\
\hline
\end{tabular}

Dari Tabel 3 dapat dilihat bahwa pada Proyek 1 dan Proyek 2 diperoleh nila $\mathrm{CV}=0$. Hal ini berarti dari kedua Proyek 1 dan Proyek 2 paket pekerjaan dapat diselesaikan sesuai dengan anggaran biaya yang direncanakan. Sendangkan pada Proyek 3 dapat terlihat bahwa pada bulan ke-1 dan bulan ke-2 memperoleh nilai $\mathrm{CV}<1$, hal ini berari paket pekerjaan yang diselesaikan melebihi anggaran yang direncanakan.

Sedangkan dari kinerja waktu, pada Proyek 1 dapat menyelesaikan paket pekerjaan lebih cepat dari jadwal rencana. Pada Proyek 2 paket pekerjaan dapat diselesaikan sesuai dengan rencana. Pada Proyek 3 di bulan pertama paket pekerjaan dapat diselesaikan lebih cepat dari rencana, di bulan kedua sesuai dengan rencana, dan di bulan ketiga lebih lambat dari rencana. Jika disimpulkan kinerja biaya dan waktu dari penggunaan standar WBS pada ketiga proyek ini adalah sebagai berikut.

Tabel 5. Kondisi Proyek 1

\begin{tabular}{cl}
\hline $\begin{array}{c}\text { Bulan } \\
\text { ke }\end{array}$ & \multicolumn{1}{c}{ Kondisi Proyek } \\
\hline 1 & $\begin{array}{l}\text { Pekerjaan selesai lebih cepat dari jadwal } \\
\text { dengan biaya sesuai dengan anggaran }\end{array}$ \\
\hline 2 & $\begin{array}{l}\text { Pekerjaan selesai lebih cepat dari jadwal } \\
\text { dengan biaya sesuai dengan anggaran }\end{array}$ \\
\hline 3 & $\begin{array}{l}\text { Pekerjaan selesai lebih cepat dari jadwal } \\
\text { dengan biaya sesuai dengan anggaran }\end{array}$ \\
\hline
\end{tabular}

Tabel 6. Kondisi Proyek 2

\begin{tabular}{cl}
\hline $\begin{array}{c}\text { Bulan } \\
\text { ke }\end{array}$ & \multicolumn{1}{c}{ Kondisi Proyek } \\
\hline 1 & $\begin{array}{l}\text { Pekerjaan selesai sesuai jadwal dan biaya } \\
\text { sesuai dengan anggaran }\end{array}$ \\
\hline 2 & $\begin{array}{l}\text { Pekerjaan selesai sesuai jadwal dan biaya } \\
\text { sesuai dengan anggaran }\end{array}$ \\
\hline 3 & $\begin{array}{l}\text { Pekerjaan selesai sesuai jadwal dan biaya } \\
\text { sesuai dengan anggaran }\end{array}$ \\
\hline
\end{tabular}

Tabel 7. Kondisi Proyek 3

\begin{tabular}{cl}
\hline $\begin{array}{c}\text { Bulan } \\
\text { ke }\end{array}$ & \multicolumn{1}{c}{ Kondisi Proyek } \\
\hline 1 & $\begin{array}{l}\text { Pekerjaan selesai lebih cepat dari jadwal } \\
\text { dengan biaya melebihi anggaran }\end{array}$ \\
\hline 2 & $\begin{array}{l}\text { Pekerjaan selesai sesuai dengan jadwal } \\
\text { dengan biaya melebihi anggaran }\end{array}$ \\
\hline 3 & $\begin{array}{l}\text { Pekerjaan selesai terlambat dari jadwal } \\
\text { dengan biaya lebih kecil dari anggaran }\end{array}$ \\
\hline
\end{tabular}

Pada tabel-tabel kondisi proyek yang digambarkan di atas, dapat terlihat bahwa dari penggunaan standar WBS pada proyek pembangunan Gedung $X$ dan Gedung Kuliah Y menunjukkan kinerja biaya dan waktu yang baik. Sedangkan pada pembangunan Gedung Olah Raga Z kinerja biaya dan waktunya tidak stabil.

Hasil penilaian kondisi proyek tersebut terkait dengan dampak lain penggunaan standar WBS berdasarkan hasil kusioner lanjutan. Pada Proyek 1 dampak penggunaan standar WBS dalam pelaksanaan proyek antara lain: 
- Pembagian kategori setiap paket pekerjaan menjadi lebih jelas.

- Perencanaan volume material dan anggaran lebih baik.

- Pembuatan Pusrchasing Order (PO) lebih terkontrol.

Pada Proyek 2 dampak yang dirasakan dari penggunaan standar WBS antara lain:

- Penggunaan standar WBS memudahkan dalam mengontrol kinerja biaya dan waktu.

- Memudahkan dalam pengendalian yang terintegrasi dengan sistem pusat, terutama pada saat pengadaan material, sehingga ahrga lebih terkendali dan stabil.

Sedangkan pada Proyek 3, dampak yang dirasakan dari penggunaan standar WBS ini dalam pembangunan Gedung Olah Raga Z antara lain:

- Penggunaan standar WBS kurang memberikan pengaruh terhadap kinerja biaya dan waktu.

- Item pekerjaan yang ada di dalam standar WBS kurang sesuai dengan kondisi proyek.

Di dalam PMI, 2005 menyebutkan kinerja biaya proyek yang baik menunjukkan keefektifan tim proyek dalam mengelola sumber daya. Hal tersebut didukung oleh pernyataan Lotffy, 2014, bahwa WBS merupakan hirarki penyelesaian lingkup pekerjaan yang harus diselesaikan oleh tim proyek sesuai dengan persyaratan produk yang akan dihasilkan.

Berdasarkan pernyataan dampak pengunaan standar WBS pada Proyek 1 (Gedung X) dan Proyek 2 (Gedung Kuliah Y), terlihat bahwa penggunaan standar WBS memudahkan tim dalam mengelola dan mengendalian proyek. Hal tersebut dapat terihat bahwa tim proyek lebih mudah dalam mengontrol penggunaan sumber daya yang ada, sehingga tim dapat bekerja dengan efektif dan efisien.

Pada Proyek 3 (Gedung Olah Raga Z) terlihat bahwa tim proyek kesulitan dalam mengelola dan mengendalikan proyek. Pada proyek tersebut dikatakan bahwa item pekerjaan yang ada di dalam standar WBS tidak sesuai dengan kondisi proyek. Sehingga perlu dilakukan penyesuaian standar WBS bangunan gedung terhadap proyek yang akan dikerjakan.

\section{KESIMPULAN}

Penetapan lingkup pekerjaan sejak awal proyek akan memudahkan dalam pelaksanaan maupun dalam proses pemantauan dan pengendalian. Penetapan lingkup pekerjaan dengan menggunakan standar WBS akan memudahkan anggota tim proyek dalam menjalankan pekerjaan. Dengan menggunakan standar WBS, pembagian lingkup pekerjaan menjadi level terkecil memudahkan setiap item pekerjaan untuk dikelola. Termasuk dalam pengelolaan sumber daya yang akan digunakan.

Penggunaan standar WBS dalam pelaksanaan proyek erat kaitannya dengan kinerja biaya dan waktu proyek. Standar WBS digunakan sebagai dasar dalam estimasi biaya dan waktu pelaksanaan proyek. Dengan penggunaan standar WBS, baik dalam proses perencanaan maupun pelaksanaan akan berdampak pada kinerja proyek. Hal tersebut dapat terlihat pada proyek-proyek bangunan gedung yang ditinjau dalam penelitian ini.

Dari penelitian ini diperoleh hasil pada pembangunan Gedung X dan Gedung Kuliah Y menunjukkan kinerja biaya dan waktu yang baik. Sedangkan pada pembangunan Gedung Olah Raga Z kinerja biaya dan waktu yang ditunjukkan kurang stabil.

Berdasarkan dampak penggunaan standar WBS yang dirasakan oleh tim proyek pada pembangunan Gedung $X$ dan Gedung Kuliah Y sangat membantu dalam pengendalian proyek. Hal tersebut dikarenakan item pekerjaan yang akan dikelola menjadi lebih terperinci, sumber daya yang dibutuhkan menjadi lebih jelas, sehingga memudahkan dalam perencanaan Purchasing Order (PO), akibatnya pengendalian biaya menjadi lebih mudah.

Dampak penggunaan standar WBS bangunan gedung kurang dirasa manfaatnya pada proyek pembangunan Gedung Olah Raga Z. Hal ini dikarenakan terdapat itemitem pekerjaan di dalam standar WBS yang kurang sesuai dengan kondisi proyek. Dapat disimpulkan bahwa standar WBS bangunan gedung tersebut kurang sesuai jika digunakan pada proyek bangunan gedung olah raga. Perlu dilakukan penyesuaian item-item pekerjaan untuk gedung-gedung yang memiliki fungsi khusus, seperti gedung untuk fasilitas olah raga.

\section{UCAPAN TERIMA KASIH}

Penulis mengucapkan terima kasih kepada pihak-pihak yang telah membantu dalam menyelesaikan penelitian ini. Pertama, kepada Fakultas Teknik Universitas Pancasila yang membiayai penelitian ini melalui hibah penelitian internal. Kedua, kepada pihak PT. PP (Persero) yang telah bersedia membantu penulis dalam memperoleh data-data proyek.

\section{REFERENSI}

Akrami, A. A. (2015, January). Consequences of Improper Preparation of Work Breakdown Structure (WBS) and Schedule of Civil Projects. Advances in Environmental Biology (AENSI Journals), 9(2), 434-437. Cited in https://www.researchgate.net/publication/33255 3041 Consequences of improper preparation a work breakdown structure WBS and sched ule of civil projects. [2 Februari 2019]

Hans, R. T. (2013). Work Breakdown Structure: A Tool For Software Project Scope Verification. International Journal of Software Engineering \& Applications (IJSEA). Vol.4, No.4, July 2013. Cited in https://www.researchgate.net/publication/25578 7340 Work Breakdown Structure A Tool for Software Project Scope Verification. Februari 2019] 
Messah, Y. A., Lona, L. H., \& Sina, D. A. (2013), September). Pengendalian Waktu dan Biaya Pekerjaan Konstruksi Sebagai Dampak dari Perubahan Desain (Studi Kasus Embung Irigasi Oenaem, Kecamatan Biboki Selatan Kabupaten Timor Tengah Utara). Jurnal Teknik Sipil, 2(2), 121-132.

PMI. (2005). Practice Standard for Earned Value Management. Newton Square, Pensylvania: Project Managemet Institute, Inc.

PMBOK Guide - Sixth Edition (2018). A guide to the Project Management Body of Konwledge. Project Management Institute. Pensylvania.

Sediyanto, \& Hidayat, A. (2017, Januari). Analisa Kinerja Biaya dan Waktu Pada Pelaksanaan Proyek Konstruksi dengan Metode Earn Value (Studi Kasus Proyek Konstruksi Mall dan Hotel $X$ di Pekan Baru). Jurnal Ilmu Teknik dan Komputer, 1(1), 36-51.

Supriadi, L. S., Latief, Y., Susilo, B., \& Rajasa, M. (2017). Development of Risk-Based Standardized WBS (Work Breakdown Structure) for Cost Estimation of Apartement's Project. International Journal of Clvil Enginnering and Technology (IJCIET), 822-833.

Van Wyngaard, C. J., Pretorius, J. H. C., Pretorius, L. (2012). Theory of the Triple Constraint - a Conceptual Review. Preceedings of the 2012 IEEE IEEM. 